\title{
Decisão e Secularização na Reflexão de Juventude de Carl Schmitt*
}

\author{
Pedro H. Villas Bôas Castelo Branco ${ }^{1}$
}

${ }^{1}$ Universidade do Estado do Rio de Janeiro (UERJ), Rio de Janeiro, RJ, Brasil. E-mail:

pvillasboascb@gmail.com

\section{INTRODUÇÃO}

\begin{abstract}
reflexão política e jurídica de Carl Schmitt (1988-1985) projetou-o A como um dos pensadores mais notáveis e controvertidos do século XX. Seus quase 100 anos de vida atravessaram as duas grandes guerras mundiais e permitiram-lhe produzir uma vasta obra de mais de 50 livros e aproximadamente 500 artigos. A elaboração conceitual e algumas interpretações proféticas legadas pelos seus trabalhos apresentam ampla repercussão no debate contemporâneo concernente a temas centrais da filosofia política, do direito constitucional e da política internacional. As ideias de Schmitt ganharam destaque em discussões cujo conteúdo gravita em torno de questões relativas à primazia do político, ao declínio da soberania estatal, à polissemia do conceito de Constituição, à secularização, às mutações espaciais, temporais e tecnológicas dos conflitos bélicos. Seus estudos também põem em cena, no debate contemporâneo, a discussão sobre o estado de exceção, a perda das distinções entre amigo-inimigo, os limites da democracia liberal, o fetichismo da lei, a irredutibilidade do político.
\end{abstract}

Sua participação no Terceiro Reich e posterior deposição, respectivamente em 1933 e 1936, condenou-o ao ostracismo na pequena cidade de Plettenberg, onde nasceu e viveu a maior parte da vida. Não fosse a

\footnotetext{
* Gostaria de expressar meu agradecimento ao professor Cesar Guimarães (IESP-UERJ) pela gentileza em ler meu artigo e pelos comentários profícuos.
}

DADOS - Revista de Ciências Sociais, Rio de Janeiro, vol. 60, n-4, 2017, pp. 1143 a 1176. 
recuperação de suas ideias na década de 1960 por grupos de esquerda, é possível que parte significativa de seus estudos permanecesse desconhecida. A crítica iconoclasta de Schmitt aos fundamentos políticos do liberalismo atraiu na década de 1930 a atenção de jovens socialistas como Franz Neumann, Otto Kirchheimer e Walter Benjamin. Como lembra Hartmut Becker, em Die Parlamentarismuskritikbei Carl Schmitt und Jürgen Habermas (A Crítica ao Parlamentarismo por Carl Schmitte Jürgen Habermas), na década de 1980, "Ellen Kennedy ateia fogo na discussão sobre a polêmica recepção de Schmitt ao afirmar que, junto a Kirchheimer e Benjamin, Habermas também teria acolhido as argumentações de Schmitt" (Becker, 2001:10-13).

Na década de 1960, Jürgen Habermas será, paradoxalmente, um dos responsáveis pela recuperação das ideias de Schmitt, em seu livro Strukturwandel der Öffentlichkeit (Mudança Estrutural da Esfera Pública, de 1961). Nessa obra, Habermas cita Carl Schmitt de modo explícito pelo menos oito vezes, contribuindo para trazer o jurista de volta à cena do debate público. Embora o livro Die geistgeschichtliche Lage des heutigen Parlamentarismus (A Situação Histórico-espiritual do Parlamentarismo Atual) seja o escrito de Schmitt no qual Habermas alicerce parte substantiva de seus argumentos, também faz referência e utiliza os trabalhos Die Verfassungslehre (A Teoria da Constituição), Der Leviathan in der Staatlehre des Thomas Hobbes. Sinn und Fehlschlag eines politischen Symbols (1938) (O Leviatã na Teoria do Estado de Hobbes. Sentido e Falha de um Símbolo Político), publicados pela primeira vez, respectivamente, em 1923, 1928 e 1938.

Pontos centrais da argumentação schmittiana são incorporados pelo trabalho de Habermas a fim de mostrar como a esfera pública burguesa emerge da diferenciação entre foro íntimo e foro externo durante as guerras civis religiosas do século XVII. A esfera pública burguesa torna-se visível a partir da inversão mediante a qual o espaço privado da burguesia liberal adquire primazia em relação ao âmbito público da monarquia absolutista.

Embora seus trabalhos tenham sido objeto de ampla recepção em diversos países, e se perceba no Brasil um crescente interesse por sua obra, a maioria dos escritos de juventude ainda são pouco conhecidos. Este artigo pretende revisitar o texto de juventude, Gesetz und Urteil. Eine Untersuchung zum Problem der Rechtspraxis (Lei e Julgamento. Uma Investigação sobre o Problema da Práxis do Direito $)^{1}$, publicado pela pri- 
meira vez em 1912, com o propósito de caracterizar a fase inicial de elaboração de alguns de seus conceitos centrais, precisamente os de secularização, teologia política e decisionismo.

O motivo pelo qual não há uma significativa recepção dos primeiros trabalhos de Carl Schmitt é que seus primeiros escritos, a exemplo de Schuld und Schuld Arten (Culpa e Formas de Culpa) (1910), Gesetz und Urteil (Lei e Julgamento) (1912), Der Wert des Staates. Und die Bedeutung des Einzelenen (O Valor do Estado e Significado do Indivíduo) (1914), são considerados "excessivamente jurídicos" ${ }^{2}$. A sentença condenatória proferida sobre esses trabalhos vem sendo, porém, gradualmente superada, sobretudo em razão do reconhecimento de sua relevância para a compreensão do conjunto da obra de Schmitt, bem como para desmistificar interpretações alicerçadas no argumento de sua pretensão a uma teologização do político, isto é, o empenho em sacralizar a instância estruturante da realidade social. A distinção entre o político e a política desempenha papel axial na reflexão de Schmitt e encontra ressonância em trabalhos de diversos autores, como Chantal Mouffe, Ernesto Laclau, Reinhart Koselleck, Julien Freund, Jacques Derrida, Antonio Negri, Giorgio Agamben, entre outros.

Enquanto o político corresponde à forma, ao conflito estruturante e fundacional de toda sorte de comunidade e ordem, a política é historicamente determinada. Em Schmitt, a primazia do político em relação à política e ao direito advém da elaboração do conceito de decisão, cujo desenvolvimento tem início no texto sobre a lei e a decisão judicial (Gesetz und Urteil), que será discutido adiante. A decisão existencial e supraindividual corresponde à ação de um sujeito (indeterminado, contingente) capaz de fundar e estruturar a vida social e dotá-la de forma, sentido e conferir-lhe medida, enfim, existência coletiva ${ }^{3}$. Ao criar e configurar a vida social, o sujeito soberano, a fim de não se tornar um déspota, deve tornar-se supérfluo, oculto, já que criou a normalidade, pavimentou o curso regular da vida social ordinária orientada pelas normas (Schmitt, 1994:XVII). As normas e a normalidade da vida social somente adquirem validade e vigência quando uma decisão soberana cria as condições de possibilidade para seu funcionamento, como Schmitt virá a observar posteriormente no Der Begriff des Politischen, de 1927: a decisão soberana da autoridade estatal "[...] cria a situação normal que é pressuposto para que as normas possam valer de modo geral, porque toda norma pressupõe uma situação normal [...]" (Schmitt, 2002b:46). 
O presente artigo está dividido em quatro partes: a primeira consiste de uma breve nota introdutória à semântica do conceito de secularização nos primeiros escritos de Carl Schmitt. Argumenta que o sentido secularizante do primeiro trabalho, redigido após sua tese de doutorado, é uma chave indispensável à compreensão de alguns dos conceitos mais relevantes de sua obra. A segunda perscruta a tensão entre lei e decisão diante do mistério da vontade do legislador. Busca compreender o modo pelo qual a então "hermenêutica tradicional", monopolizada pelo positivismo jurídico, imputava existência objetiva e concreta à realidade abstrata e vazia da lei. A terceira explora as afinidades entre jurisprudência ${ }^{4} \mathrm{e}$ teologia e suas possíveis repercussões para a interpretação da lei e a ação de julgar. A quarta e última parte analisa pontos de convergência e divergência entre Schmitt e o movimento do direito livre. Tal movimento, como veremos, tratava de uma corrente teórica do direito que, a despeito de procurar libertar a decisão judicial da sujeição à lei, não lograva emancipá-la das operações lógicas do formalismo positivista. O presente estudo propõe-se explicitar o sentido secularizante das ideias que Carl Schmitt opõe à racionalização, formalização e ao pretenso desencantamento do direito, levados a cabo pelo positivismo jurídico. Ver-se-á o modo pelo qual o jurista sustentará a necessidade de emancipar (secularizar) a decisão judicial das rédeas da vontade da lei. A finalidade deste artigo, portanto, é mostrar que parte significativa do repertório conceitual de Carl Schmitt foi desenvolvida em seu livro sobre a lei e a decisão. A despeito de a elaboração inicial dos conceitos secularização, decisão, exceção e soberania se encontrarem em Gesetz und Urteil (Lei e Julgamento), o trabalho ainda é relegado a um segundo plano pela maioria dos estudos dedicados à obra do jurista.

\section{BREVE NOTA INTRODUTÓRIA À SEMÂNTICA DO CONCEITO DE SECULARIZAÇÃO NOS PRIMEIROS ESCRITOS DE CARL SCHMITT}

O conceito de secularização apresenta uma notável amplitude semântica na obra de Schmitt. Tanto nos primeiros escritos quanto no conjunto de sua obra, revela dois sentidos ambivalentes relacionados às noções de visibilidade e invisibilidade. $\mathrm{O}$ primeiro sentido adquire densidade a partir da crítica à acepção iluminista do conceito de secularização. A despeito de promover secularizações, a secularização iluminista não secularizaria de fato, pois ao pôr elementos terrenos no lugar daqueles de cunho sagrado, conserva um fundamento metafísico cujo resultado não seria outro senão sacralizar. Ao não se diluir ou 
alijar o alicerce metafísico - forjado pelo fermento de uma crença capaz de projetar uma imagem - substituir-se-ia Deus por uma concepção demiúrgica de lei, razão ou ciência. Neste caso, secularização aparece como substituição do sagrado pelo terreno, mas o elemento terreno conserva um resíduo sagrado, ainda que de modo invisível. Como dirá Schmitt, Deus pode ser substituído pela história, nação, indivíduo, lei, mas tais elementos terrenos guardam em sua estrutura reminiscências sagradas: "[...] aquilo que os homens consideram como última instância absoluta pode mudar, e Deus pode ser substituído por fatores terrenos deste mundo. É a isso que chamo de secularização [...]" (Schmitt, 1998c:18).

Embora marque o sentido da secularização iluminista com um sinal negativo, o jurista também confere ao conceito uma acepção positiva, e o faz desde seus primeiros escritos. O segundo sentido do conceito, portanto, surge relacionado à ideia de visibilidade e se refere ao empenho em tornar visível uma ideia no mundo. Em virtude de uma lei ser incapaz de autorrealizar-se e adquirir uma dimensão concreta convém pôr a ideia do direito no mundo empírico por meio da atividade decisória do ser humano. A lei - abstração genérica - não entra no mundo da realidade sem uma atividade decisória proveniente de um sujeito de carne e osso. A decisão - ato secularizante que põe a ideia no mundo - não advém do plano ideal da norma, mas do plano existencial da realidade concreta. Seu traço existencial residiria no fato de as contingências da realidade dinâmica pressionarem por uma decisão voltada à configuração da vida social. Não é a pretensa causalidade normativa, mas a decisão é que é a força capaz de realizar o direito e reduzir os níveis de indeterminação em sociedades crescentemente complexas. A secularização da ideia do direito, por meio da decisão desconectada da racionalidade normativa, corresponde à construção embrionária do conceito do político de Schmitt. Em outras palavras, a decisão é a força soberana que cria o direito em estado de exceção com relação à anterioridade da norma, pois não se orienta por esta, mas pelas demandas da situação concreta da realidade.

Ao denunciar o fetichismo da lei e propugnar pela sua emancipação das amarras da crença positivista no legislador onipotente ou na lei absoluta, Schmitt revela um dos sentidos da secularização: secularização é um modo de tornar visível o direito no mundo empírico por meio de uma decisão. Desse modo, se o direito for reduzido à lei, será invisível e a vida social marcada por elevados níveis de contingência, mas se for 
secularizado, por meio da decisão, adquire visibilidade e confere previsibilidade à vida social. Em virtude disso, o jurista negava a máxima norma coelitus hausta (norma extraída do céu), porque o que torna a norma concreta e visível é a decisão. Pensar o direito como se fosse limitado à norma significaria acreditar que sua eficácia poderia ser extraída do céu, da autoctonia do intelecto. A decisão, porém, é uma atividade prática que põe o direito no mundo (Castelo Branco, 2011:188 e 189). O conceito de decisionismo é desenvolvido no primeiro texto escrito após sua tese de doutorado e resulta em sentido secularizante, que permeia toda sua obra de 1910 a 1978, como é possível constatar em sua correspondência com Hans Blumenberg (Schmitt, 2007:143). Dois anos após a publicação de Gesetz und Urteil, Schmitt, em Der Wert des Staates (1914), emprega o termo secularização pela primeira vez e o faz exatamente com o sentido já presente no trabalho sobre a lei e a decisão judicial. Secularização surge com o sentido de um esforço em tornar algo visível (Sichtbarmachung):

Deve-se, ainda, chamar a atenção para um fenômeno cuja discussão constitui, adequadamente, a conclusão sobre Estado e direito: tão logo se manifeste em alguma parte o esforço de uma realização de ideias, de um tornar visível (Sichtbarmachung) de uma secularização (Säkularisierung), surge imediatamente - ao lado de uma decisão concreta que tem de ser, sobretudo, determinada mesmo que seja à custa do pensamento - o empenho por uma instância determinada da mesma forma e infalível, que conceda esta formulação (Schmitt, 2004a:81; ênfases minhas).

Como se verá, Schmitt ao se opor ao conceito abstrato de lei do positivismo jurídico, desloca a atenção da norma para a realidade concreta do direito concernente ao agir e decidir humanos. A decisão é o veículo da secularização por meio da qual o direito adquire visibilidade frente à crença no direito concebido como vontade sagrada da lei.

\section{ENIGMA DA VONTADE DO LEGISLADOR}

Subjacente à controvérsia jurídica, aduzida no escrito de juventude Gesetz und Urteil, encontra-se o estágio inicial da preocupação política presente nas diferentes fases da reflexão de Carl Schmitt: a ausência de legitimidade da decisão proferida em conformidade com a lei. O núcleo central da crítica do jurista alemão residia no fato de a secularização iluminista do conceito de lei não haver eliminado seu conteúdo teológico. Persistia a crença em uma força absoluta cujo fermento 
sagrado não havia se dissipado. Tanto a concepção iluminista de lei, do século XVIII, quanto a positivista, do final do século XIX e início do XX, não haviam perdido seu fundamento metafísico. A secularização iluminista ou positivista, conforme Schmitt, não havia secularizado o decidir e o agir políticos, mas os havia transferido, respectivamente, para uma vontade racional do indivíduo ou da lei. A razão do indivíduo ou da lei seriam formas teológicas secularizadas, pois manteriam um suporte metafísico, isto é, uma crença absoluta de modo análogo à crença em um "Deus todo-poderoso". Dez anos após a primeira edição de Gesetz und Urteil, no trabalho Politische Theologie. Vier Kapitel zur Lehrevon der Souveränität (Teologia Política. Quatro Capítulos sobre a Lição da Soberania), publicado pela primeira vez em 1922, enuncia:

Todos os conceitos relevantes da teoria do Estado moderno são conceitos teológicos secularizados. Isso vale tanto para o seu desenvolvimento histórico -, já que foram transferidos da teologia para a teoria do Estado, transformando-se, por exemplo, o Deus todo-poderoso no legislador onipotente - quanto para sua estrutura sistemática, cujo conhecimento é necessário para uma consideração sociológica dos conceitos. (Schmitt, 2004b:43)

O estágio inicial do conteúdo do célebre enunciado, surgido pela primeira vez em uma coletânea dedicada à memória de Max Weber, encontra sua raiz em Gesetz und Urteil. No aludido trabalho, concernente aos conceitos de lei e decisão judicial, Schmitt já se empenhava em mostrar que por trás da fachada do discurso sustentado na racionalidade da ciência positivista, o positivismo jurídico se apoiava em uma base irracional. Alicerçava-se em uma crença cujo teor deslocara seu objeto de um "Deus todo-poderoso" para "legislador onipotente". Ora, nessa substituição da fé em Deus pela fé no legislador, a substância do sagrado não havia esvanecido, mas permanecido no fundamento metafísico de uma crença velada. O deslocamento de objeto não havia alijado uma estrutura comum: a imagem metafísica do mundo. $\mathrm{O}$ resíduo sagrado havia remanescido e servido de fermento para tornar totalitário o conceito de lei (Castelo Branco, 2011:213). A vontade da lei abstrata e generalizante seria transcendente e independente de qualquer vontade humana. Em virtude disso, Schmitt buscará desvelar o caráter absoluto e tirânico do valor imputado à lei e da ilusão do princípio da legalidade, pois não é a lei que governa os homens, mas são homens que governam homens. O texto de juventude de Schmitt é epítome de um dos maiores desafios enfrentados ao longo de quase toda a 
sua vida: o combate ao fundamento absoluto ao qual fora alçada a concepção de lei, sobretudo a partir da instauração do positivismo jurídico na segunda metade do século XIX, na Europa.

Desde cedo o jurista percebera que todo Estado de direito, cujo fundamento reside no conceito absoluto de lei, se encontraria no limite fronteiriço do "estado de emergência (Notstand)" (Schmitt, 1912:9), pois a crença na supremacia da legalidade em relação à legitimidade provocaria indeterminação ${ }^{5}$ do e no ordenamento jurídico. Para Carl Schmitt, o estado de emergência (Notstand) em que se encontrava o juiz no início do século XX, era consequência da "[...] impossibilidade de um conteúdo normativo se tornar efetivo por si mesmo [...]" (Ferreira, 2004:100). O eixo gravitacional de sua teoria correspondia ao caso concreto da realidade empírica e não a um conjunto de normas jurídicas abstratas capazes de se autorrealizarem por meio de uma pretensa vontade imanente. $\mathrm{O}$ direito não poderia ser reduzido a leis, seu conteúdo somente se tornaria realidade a partir de uma decisão orientada, não pela normatividade abstrata, mas pela singularidade dos casos concretos contingentes da realidade complexa. O jurista entendia que o centro das crenças se deslocava da soberania estatal à soberania da lei, de modo que nem a monarquia constitucional, nem tampouco a democracia liberal logravam eliminar a condição de possibilidade de um núcleo absoluto. Em outras palavras, o centro da soberania é contingente e se desloca em conformidade com o fundamento das crenças capazes de projetar uma imagem do mundo (Weltanschauung) que encontre uma estrutura análoga na realidade. Posteriormente, Schmitt afirma que a democracia tampouco exclui a ditadura de seu núcleo semântico (Ferreira, 2004:115). O conceito absolutista de lei, no qual representantes do positivismo jurídico haviam depositado uma fé cega, poderia produzir "um estado de emergência" independentemente da forma de governo assumida pelo Estado de direito. Desde seu primeiro escrito em questão, o jurista alemão tinha clareza quanto ao fato de que qualquer concepção absoluta de lei, poderia suscitar uma indeterminação na vida social, como era o caso do "estado de emergência do juiz" (Schmitt, 1912:9). A despeito de Agamben servir-se sobretudo das ideias de Schmitt, em Estado de Exceção, e revelar ter conhecimento de Gesetz und Urteil, ele não esclarece que sua formulação segundo a qual "o estado de exceção apresenta-se [...] como um patamar de indeterminação entre absolutismo e democracia" (Agamben, 2004:13) já continha seu embrião no aludido escrito de Schmitt. Qualquer forma estatal fundada na crença na onipotência do princípio da legalidade 
refletia a "fetichização da lei", a qual poderia resultar em um "estado de emergência do juiz" (Schmitt, 1912: 9 e 25).

Embora demonstre em seus trabalhos conhecimento dos escritos de juventude de Schmitt, Agamben não percebe que neles já está presente a ideia de contingência e indeterminação, as quais contribuem para o jurista alemão desenvolver sua teoria da exceção, cujo teor é imprescindível ao desenvolvimento do seu conceito do político.

A investigação da conexão estabelecida pelo positivismo estatal entre a lei positiva e sua aplicação no âmbito da prática jurídica descortinava a necessidade de a decisão ser "conforme a vontade do legislador" ou da lei. O exame dos métodos voltados à sua apreensão revelava a difundida crença na transmissão dessa vontade pela via da decisão judicial "correta" à "solução" de um caso concreto da realidade empírica. A fé na lei, porém, alicerçava-se na veleidade de uma "vontade" que flutuava da "vontade real do autor da lei", ou da vontade do "legislador' empírico concreto", para a "vontade da lei".

Ao dedicar-se à investigação da "vontade do legislador" no livro acima aludido, Schmitt busca desvendar o enigma subjacente à vontade do autor da lei ou do legislador histórico, as razões do deslocamento dos procedimentos hermenêuticos do alcance da vontade do legislador para a vontade da lei ou do texto. O mistério da translação da vontade do legislador à vontade da lei pode ser decifrado no exame do caminho da transição da subjetividade da vontade até sua objetivação. A vontade da pessoa concreta, situada no tempo e no espaço, se eleva à grandeza de uma vontade objetiva impessoal, não apenas desenraizada do espaço de sua experiência, mas também dos motivos de sua criação. A evolução dos procedimentos de interpretação da lei narravam o processo pelo qual a pretensa vontade pessoal se torna independente do seu criador, autônoma em relação ao conteúdo, isolada do corpo parlamentar, transcendente à vontade popular. A lei, ao ser elevada à grandeza autônoma, objetiva e impessoal, purificava-se das vontades divididas ou da fragmentação política da qual havia resultado, possibilitando sua racionalização e sacralização. Tal concepção predominante da lei encontrará na ciência do direito e na práxis jurídica os representantes e portadores indispensáveis de sua "razão objetiva" (Schmitt, 2003a:402). Não por acaso Schmitt ironizava o topos positivista cujo teor revelava que "a lei é sempre mais inteligente do que seu legislador" (idem:403; ênfase no original). 


\section{Breve Contexto Pré-weimariano dos Primeiros Escritos de Schmitt}

O método de interpretação da lei - vigente na jurisprudência do continente europeu no início do século passado - ligava-se à divisão de poderes do Estado prussiano, sobretudo ao traço peculiar de sua monarquia constitucional, surgida em 1848. Segundo Schmitt, em seu livro Verfassungslehre (Teoria da Constituição), de 1928, a característica dessa forma de governo era o dualismo entre o governo monárquico e a representação popular. A ambiguidade da monarquia constitucional prussiana, cujo fim fora precipitado pelo término da Primeira Guerra Mundial e pela proclamação da República de Weimar, era percebida pelo jurista alemão por meio da postergação e paralisia da decisão concernente ao sujeito da soberania política. O adiamento da decisão "resulta da alternativa: ou o príncipe ordena uma Constituição com base no princípio monárquico proveniente da plenitude de seu poder estatal, ou a Constituição se sustenta no ato do poder constituinte do povo, isto é, num princípio democrático". Para Schmitt, o "'dualismo' dessa Constituição seria insustentável", pois "no interior de toda unidade política somente pode haver um titular do poder constituinte" (Schmitt, 2003b:53). Aliás, "todo conflito autêntico revela o simples ou isto-ou-aquilo (Entweder-Oder) dos princípios políticos formais mutuamente excludentes" (idem). Contudo, não havia conflito entre burguesia liberal e monarquia, "na realidade, a Constituição, a despeito do velamento e desvio, não se funda nem no princípio monárquico nem no princípio democrático". O que, de fato, havia era um questionável "compromisso dilatório" por meio do qual o rei não renunciava ao seu poder constituinte e, concomitantemente, não reconhecia a fundamentação do poder pelo povo.

O que possibilitava a "situação intermediária" configurada no dualismo de duas representações políticas opostas? A concepção positivista do direito estatal e da Constituição associada a um liberalismo formal, sustentada por uma favorável situação política e econômica, viabilizariam a coexistência de duas posições políticas contrárias. Com a crença no positivismo legalista, isto é, "a fé na codificação e na unidade do sistema, deixava de existir o conceito puro de norma da Constituição, tal como o pressupõe a ideia liberal de Estado de direito absoluto" (idem:11). A noção positivista do conceito de Constituição, identificada com um sistema de normas, teria sido possível mediante o amálgama do positivismo jurídico com o liberalismo político. A erosão do fundamento metafísico do direito natural burguês, precisamente de sua con- 
cepção universalista e soberana da razão natural, havia aberto espaço para a transição da razão iluminista à crença no caráter absoluto da lei positiva. O fundamento último da metafísica liberal revelaria outra fonte: em vez da imutabilidade e anterioridade do direito natural, a superioridade da lei positiva como fato da realidade. Nesse sentido, o "Estado liberal de direito absoluto" não perdia o vigor de seu caráter absoluto extraído do fundamento da superioridade da lei, tal como concebida pelo positivismo legalista. Segundo Schmitt, a noção positivista da Constituição, sob a fachada da monarquia constitucional, teria permitido manter uma situação intermediária ou paradoxal. No plano teórico, frente à cisão política, a situação intermediária "foi encoberta de modo que correspondia às ideias liberais, fingindo uma 'soberania da Constituição" e, desse modo, evitando a questão essencial sobre o poder constituinte. Na prática, a situação de uma decisão procrastinada era possível na medida em que a situação da política interna e externa permanecia uniforme e tranquila (idem:54). Todavia, o problema decorria do fato de se atribuir a soberania às leis, e não aos homens (idem:146). A relativa estabilidade política havia dado origem a um conceito objetivo e impessoal de lei, erguido como uma ponte sobre o abismo da dilaceração política (Schmitt, 2003a:402). A lei, portanto, estava acima do poder político, o Estado surgia como um organismo vivo e a Constituição surgia como caída do céu (Schmitt, 2003b:55).

Ao expor a erosão do positivismo legalista, Schmitt declara de forma peremptória: "a decisão que advém da fonte da lei está esgotada" (Schmitt, 1912:23). A impossibilidade de extrair a decisão da fonte da lei reside na elevação da lei ao status de uma entidade autônoma. $\mathrm{O}$ grau de independência da lei com relação aos assuntos cotidianos da vida ordinária, motivos de sua criação, seria verificado por meio do sentido que a hermenêutica tradicional lhe atribuía. De acordo com o jurista alemão, o exame da exegese e interpretação da lei seria uma chave imprescindível à revelação do sentido transcendente imputado à vontade da lei ou do legislador. A análise da hermenêutica tradicional, monopólio do positivismo legalista, identificava a decisão correta com a interpretação correta, pois assim revelaria o espírito ou a voz secreta da vontade superior. O método adequado de interpretação poderia conduzir à escuta imediata da voz do legislador ou da lei. É claro que a própria hermenêutica tradicional percebia a existência de entraves para encontrar o caminho direto da vontade do legislador, constatando que seria mais adequado "reconstruir" suas intenções, seus desígnios, isto é, sua "vontade verdadeira". 


\section{TEOLOGIA E JURISPRUDÊNCIA: PARENTESCO HISTÓRICO-METODOLÓGICO}

Em Gesetz und Urteil, dez anos antes da publicação do livro Politische Theologie. Vier Kapitel zur Lehrevon der Souveränität (Teologia Política. Quatro Capítulos sobre a Teoria da Soberania), Schmitt já suspeitava de que a ambição pela busca da vontade do legislador ou da lei no texto de uma norma jurídica guardava uma afinidade entre a jurisprudência e a teologia. O livro de 1912 não contém apenas o desenvolvimento embrionário dos conceitos de decisão e exceção indispensáveis ao exame do conceito de teologia política, mas também a elaboração de um dos principais sentidos que, posteriormente, ele atribuirá ao conceito de secularização: o empenho em tornar visível e concreto o direito; ou seja, secularizar o direito é torná-lo visível mediante uma decisão soberana capaz de promover sua realização por meio da autoridade estatal. Muito cedo o jurista percebe que a ciência do direito, caracterizada pelo "pathos antimetafísico", por um conhecimento infalível, pela garantia de segurança jurídica, tinha paralelos com a teologia. Por isso salienta que "um paralelo como esse tem uma reivindicação de importância metodológica, porque entre a hermenêutica tradicional jurídica e a teoria da interpretação teológica também existe uma relação historicamente comprovada dos métodos" (Schmitt, 1912:127). A passagem, negligenciada pela grande maioria de seus intérpretes, demonstra que Schmitt, em seu escrito de juventude, apresenta uma reflexão sobre a analogia entre a "hermenêutica tradicional jurídica e a teoria da interpretação teológica".

Em Gesetz und Urteil, a analogia é compreendida, pela primeira vez, como um fecundo procedimento heurístico, cujo emprego permite descobrir uma afinidade histórico-metodológica entre a jurisprudência e a teologia. Tal constatação permite ao jurista descobrir o fato de a jurisprudência empregar um método estruturalmente idêntico à teologia a fim de decifrar os desígnios secretos do legislador. Por força de um processo de secularização iluminista ${ }^{6}$, o legislador não era mais o mesmo, mas ainda assim mantinha uma reminiscência notavelmente demiúrgica. No escrito de juventude em discussão, nota-se a crítica ao uso sub-reptício que a jurisprudência fazia da analogia. Por meio do dispositivo analógico inferia-se qualquer conteúdo desejado de um pretenso sistema fechado de normas jurídicas. A analogia, nesse sentido, apresentava-se como artifício capaz de ocultar a incompletude do sistema de normas ou ofuscar a transgressão constante dos limites 
epistemológicos da "ciência do direito". Por isso Schmitt entende que o emprego adequado da analogia poderia ser fértil para constatar continuidades, transferências, reciprocidades, sobretudo em meio à acelerada e arbitrária diferenciação de saberes aprofundada no início do século XX. Ao examinar o uso do método analógico pela corrente do positivismo jurídico, detentora do monopólio da concepção válida do direito, o jurista se surpreendia com o uso frequente de analogias entre direito e teologia, direito e medicina, direito e biologia, direito e matemática $^{7}$ (Schmitt, 1912:58-59).

A investigação da perspectiva analógica descortinava a incongruência da matriz positivista do direito, cuja pretensão residia na conversão do fenômeno jurídico complexo em um sistema fechado de normas. Se, por um lado, a hermenêutica positivista tradicional adotava a operação reducionista de encerramento do sistema por meio da identificação do direito à lei, por outro lado, promovia sua abertura através das analogias. Fechava-se o sistema devido à ambição "científica" de um conhecimento apodítico, mas de modo velado efetuava-se sua abertura a fim de lhe conferir vitalidade como a existente em um organismo vivo. A analogia cumpria o papel de conferir ao sistema de normas legais um funcionamento imanente, de modo que a lei adquiria alma, motor próprio pelo qual se tornava autoaplicável como se o nervo existencial da decisão lhe fosse intrínseco. Schmitt parecia observar um movimento epistemológico triplo da concepção juspositivista do direito identificado à lei: a condição de possibilidade do encerramento do sistema jurídico seria alcançada a partir de sua analogia com a lógica formal matemática e sua abertura velada por meio da analogia com a biologia, a fim de lhe conferir dinâmica própria. Assim, a lei fechada no interior do sistema normativo ganhava força animista. A analogia entre direito e teologia elevava a lei ao status demiúrgico do absoluto, cujo sentido poderia ser traduzido sob a forma de onipotência e onipresença, e que funcionava como condição de possibilidade necessária à sujeição do poder decisório do juiz à soberania do legislador.

A batalha para emancipar a decisão das amarras de uma concepção demiúrgica de lei era travada por meio da oposição do juiz ao legislador, da decisão à lei, e revelava o estágio inicial do desenvolvimento do conceito de soberania, exceção e decisão. O empenho de Schmitt no escrito de juventude - fundamental em sua obra - consiste em acentuar o atributo da soberania na decisão e não na lei. É a decisão, e não a lei, que realiza, efetiva ou concretiza o direito. Em outras palavras, en- 
quanto a decisão para o jurista é uma ação praticada por uma pessoa de carne o osso, a lei torna-se cada vez mais abstrata a ponto de a vontade deixar de ser uma qualidade humana a fim de ser qualidade legal. $\mathrm{O}$ fundamento teológico no qual se alicerçava o conceito de lei, forjado pelo positivismo jurídico, era percebido por meio da representação da lei como grandeza autônoma, animista, dotada de vontade imanente e independente da criação da criação dos próprios homens. Enquanto a lei se desenraizava da vontade humana e ganhava vontade impessoal capaz de se generalizar, a decisão do juiz deveria converter-se em uma mera operação lógico-dedutiva capaz de reproduzir a vontade da lei.

Para o jurista, é necessário observar "que o tempo de transição das ciências naturais até o seu método moderno mostra a manifestação de muitos paralelos histórico-culturais" (Schmitt, 1912:127). Em virtude disso, examina os fundamentos da formação do método científico e chama a atenção para a comparação do direito com outras áreas, como "a medicina e as ciências naturais, que podem sempre ilustrar declarações singulares." Todavia, "no que se refere à interpretação teológica, desde sempre foi familiar aos juristas comparar seus métodos com os da teologia". Segundo Schmitt, a analogia entre teologia e direito deveria ser examinada, "porque aqui uma série de ideias fundamentais encontra pontos de conexão, significando o paralelo mais do que uma interessante ilustração" (idem).

A aceitação da lei - mesmo frente à incapacidade de se determinar sua autoria, seu conteúdo, motivo, sentido ou finalidade, e de compreender a mensagem presente na vontade legislativa - tinha como fundamento a fé na lei:

Para o homem ingênuo é "bastante claro": a lei é o que o legislador [...] que "faz" a lei quer, ou seja, de fato quis, e isto, portanto, deve poder, de alguma maneira, ser verificado [...] caso ainda viva [...]; se, contudo, estiver morto, é certamente mais difícil, mas com o desenvolvimento moderno da pesquisa histórica não é impossível descobrir algo novo (idem:24).

Na passagem acima, Schmitt, ao contrário do que sugerem estudiosos ${ }^{8}$ de seus trabalhos, não só identifica a influência da hermenêutica teológica na jurisprudência, mas também repreende seu uso em razão de se atribuir um espírito à lei. $\mathrm{O}$ afã do intérprete da lei e do juiz em apreender a vontade do legislador terminava por conferir-lhe uma substância originária, inabalável, cujo teor poderia ser desvendado mediante a 
adoção do método correto de investigação. Por meio do exame dos métodos de interpretação, o jurista torna-se consciente da relevância do papel desempenhado pela teologia no âmbito da investigação jurídica. A relação entre teologia ejurisprudência permite descortinar, em plena "era da tecnicização", a existência de um sentido sagrado atribuído às leis imanentes a este mundo. Sobre o "manual de 'hermenêutica' jurídica", Schmitt afirma que, para seu autor, a "interpretação teológica e jurídica é imediatamente a mesma coisa" (idem). Embora observe que os meios de interpretação mencionados no manual dificilmente são aplicados na prática jurídica, ainda assim as decisões frequentemente se "referem ao que o redator da lei "imaginou". Ora, em plena era do progresso técnico-científico, cuja expressão também poderia ser encontrada na forma da sistematização e codificação das leis, o jurista percebe que o procedimento pelo qual se interpretavam as intenções das leis e códigos jurídicos guardava afinidade estrutural com o método interpretativo da vontade divina do legislador supremo das Escrituras Sagradas. Tanto na hermenêutica teológica quanto jurídica, o método adotado sempre buscava na lei uma vontade transcendente cuja formação era completamente desvinculada de seu intérprete ou aplicador.

A substituição da fé em um Deus, legislador do universo, pela fé em um legislador, autoridade terrena, não elimina seu caráter sagrado, absoluto, depositado em uma vontade transcendente "capaz" de organizar e estruturar a vida social. A organização político-jurídica de todas as sociedades, desde tempos imemoriais, se alicerça em fundamento metafísico oriundo das crenças humanas. Descortinar tal fundamento, tirar-lhe o véu e revelar a inexistência de uma vontade transcendente àquela proveniente de homens concretos, corresponde a um dos sentidos atribuídos por Schmitt ao conceito de secularização. Aí reside a questão fundamental da secularização que percorre grande parte da obra de Schmitt: uma concepção absolutista de lei, monopolizada pelos arautos do positivismo jurídico, retirava a responsabilidade da decisão judicial e a transferia para uma grandeza transcendente e progressivamente impessoal. A sacralização da lei culminava no ato de atribuir ao legislador e, posteriormente, à lei uma vontade imanente, autônoma, cujo resultado alijava a autoridade da responsabilidade da decisão. A transferência da responsabilidade decisória para o normativismo impessoal e abstrato provoca a perda de sentido e impede a construção de uma forma política e jurídica estável para a realidade concreta da vida humana. À luta travada contra o deslocamento do 
conteúdo da decisão para a vontade enigmática do legislador subjaz o sentido secularizante de Gesetz und Urteil que é uma chave imprescindível ao conhecimento da vasta obra do autor.

A despeito de não se encontrar o termo secularização no referido trabalho, seu núcleo semântico é observado no empenho do jurista em denunciar um conceito de lei ao qual a fé científica do positivismo jurídico atribuía o sentido de onipotência e onisciência, dotando-o de uma aura sagrada. A luta de Schmitt pela secularização da lei representava uma tentativa de solapar o monopólio da jurisprudência positivista do conceito de lei, cuja hermenêutica principal provocava sua progressiva sacralização.

Secularizar, à luz da perspectiva schmittiana, correspondia, entre outros aspectos, à necessidade de emancipar a decisão de seus pressupostos normativos. A meu juízo, é inequívoco o fato de que a transferência da decisão de homens de carne e osso à vontade da lei tolhe a responsabilidade do agir e decidir políticos na realidade da vida humana. O resultado dessa transferência implica a progressiva perda de sentido capaz de servir de medida às questões existenciais da vida humana. Desse modo, não se poderia perder de vista que "diariamente são proferidas decisões que seriam impossíveis considerar como expressão da vontade consciente do legislador. Desvios dela foram, entretanto, reconduzidos a sua suposta vontade, assim como o resultado da interpretação de uma lei" (Schmitt,1912:25). A ausência de responsabilidade do juiz fundava-se na ideia de que a "interpretação não cria nenhum conteúdo novo, mas apenas desvenda o já existente" (idem).

Embora se procure mediante a teoria da vontade do legislador alcançar a vontade do legislador histórico, "na práxis se construía o legislador ideal que sempre quer algo racional e afastava-se o legislador histórico" (ibidem:26). A despeito de Schmitt, em Gesetz und Urteil, ainda não dirigir sua análise diretamente às circunstâncias políticas do processo de objetivação e abstração das leis, observou-se, acima, que o conflito político direto entre a monarquia e a burguesia liberal fora evitado por meio de compromisso. A situação intermediária, instituída pelo compromisso subsistente até 1918, caracterizava-se pela transferência do poder às leis constitucionais e, consequentemente, pela suspensão da decisão política fundamental sobre o sujeito do poder constituinte. $\mathrm{O}$ compromisso entre a coroa e o parlamento, ao provocar o encobrimen- 
to do sujeito do poder constituinte, velava também a vontade do legislador pessoal, restando apenas a vontade da lei:

Hoje, o argumento em voga contra a observância da vontade histórica fática do legislador é o indício de que no Império alemão (Deutschenreich) não há absolutamente nenhum legislador pessoal. Por isso, fala-se, atualmente, em geral, apenas na vontade da lei. (Schmitt,1912:26)

No Império alemão, no lugar da vontade constitucional pessoal do legislador histórico surgia a vontade impessoal da lei. No que se refere à "vontade do legislador", Schmitt constatava a relutância dos juristas positivistas em admitir um tratamento dos conteúdos jurídicos "como se fossem a vontade do legislador". De acordo com seu ponto de vista, a ficção em si não representa nenhum problema, pois na medida em que se tem consciência dela, existe a possibilidade de aprimorar a teoria da interpretação. Contudo, a ausência de consciência ou o encobrimento do procedimento fictício, a exemplo de "um argumento-comose (als-ob-Betrachtung)", conduz à conversão do "como se em porque" (Schmitt, 1912:26). Desse modo, uma ficção se converte em um dogma.

Mediante o pretenso avanço da "teoria da vontade", abandonava-se a "vontade do legislador" e alcançava-se outro estágio: a "vontade da lei". A fase caracterizada pela "nova expressão da vontade da lei" teria livrado o juiz ou o intérprete da lei de estender sua interpretação às intenções do legislador por meio do exame dos materiais, discussões em comissões, e assim por diante. Portanto a "lei passa a ser somente o que é publicado como lei. Por isso, os materiais de uma lei, as discussões de uma comissão, qualquer opinião privada, não são mais lei" (ibidem:27). A nova fase da "teoria da vontade" buscava tornar patente a impossibilidade de se:

investigar o conteúdo de vontade psicológica e real de determinada pessoa como, por exemplo, a de Justiniano, ou Frederico, o Grande, em determinado espaço de tempo, pois esse empreendimento é claramente absurdo quando se trata da "vontade" de uma assembleia legislativa. (idem)

A teoria da vontade da lei, ao transitar da vontade subjetiva do legislador à vontade objetiva da lei, passava a ser designada também de teoria objetiva da lei ${ }^{9}$. Segundo essa teoria, a vontade da lei teria um caráter teleológico cujo conhecimento somente poderia ser alcançado por um "homem racional" (ibidem:31). Assim não haveria diferença essen- 
cial entre as teorias objetiva e subjetiva, da vontade, pois a teoria objetiva da lei:

leva, da mesma forma que a "vontade do legislador", à construção de um legislador racional e é, de fato, indiferente se sua argumentação é carimbada com o selo da "vontade indubitável do legislador", ou da "vontade indubitável da lei" se a competência da vontade da lei não está, de modo algum, clara. (idem)

Ambas as teorias da interpretação não conseguiam abandonar a ideia de uma "vontade flutuante", sempre verdadeira e racional, a pairar acima do intérprete ou do juiz (ibidem:32). Uma vontade que, por sua vez, legitimava-se a si mesma por meio de uma correta via de interpretação. O problema é que o "esclarecimento do vago conceito de vontade teria sido tão necessário quanto os esplêndidos ataques ao 'fantasma legislador'". Dele se estava livre, porém "a 'vontade', o pior fantasma, havia permanecido" (ibidem:30).

Frente à notável insistência com que os seguidores do positivismo jurídico atribuíam uma vontade à lei, cujo conteúdo era exterior à vontade humana, Schmitt se empenhava em secularizar a decisão, isto é, emancipá-la da "vontade do legislador ou da lei" e imputá-la à vontade e responsabilidade de homens concretos. A decisão é um predicado da vontade humana concreta e não da vontade autônoma de uma norma abstrata, cujo conteúdo somente seria acessível por meio de interpretações idênticas às interpretações teológicas. Enquanto o conceito positivista de lei corresponde ao mundo espiritual, aos poderes invisíveis da vontade legisladora do mundo vindouro, a concepção schmittiana de julgamento concerne ao mundo temporal, à decisão proferida por homens, juízes deste mundo secular. A decisão é uma atividade que emana da vontade secularizada de juízes e não da vontade divinizada da lei. A insistência deste artigo no sentido secularizante das ideias do jurista se deve ao fato de suas ideias, desde os primeiros escritos, apresentarem inequívoca repercussão política: compreendida como problema da responsabilidade do agir e decidir neste mundo. A ressonância política do referido problema poderia ser compreendida da seguinte maneira: se a existência de uma vontade imanente à lei se apoia na fé cega em uma razão legal, logo essa mesma fé legitima que a decisão fundada na vontade imanente à lei transfira-lhe sua responsabilidade. Quem decide, então, não é soberano e tampouco responsável, pois a lei sacralizada é responsável. Daí infere-se ser o juiz, cuja decisão se fundamenta em conformidade com lei, irresponsável. Aqui 
nota-se a afinidade estrutural com as ideias de Weber no concernente ao tema da ética da responsabilidade e da ética da convicção. O conceito schmittiano de decisão deriva de um nada normativo, haja vista se orientar em conformidade com a realidade concreta e não de acordo com o princípio da anterioridade de uma vontade abstrata generalizada, cega à singularidade da realidade empírica.

O último estágio, salientado por Schmitt, consiste na fundamentação da decisão somente com fulcro na "lei", de modo que, no delinear do positivismo, excluir-se-ia da lei a sua "vontade". O processo de formalização e generalização faria o conceito de lei perder a "vontade" e atingir o grau máximo de impessoalização, cujo teor equivaleria à desumanização observável na racionalidade legal da dominação burocrática (Weber, 2005:718). A decisão, cujo pressuposto inextirpável é o caráter contingente da existência humana, provém dos próprios seres humanos concretos e não de uma divindade onisciente e onipresente, dotada de forma genérica e abstrata. Do ponto de vista positivista, tal conceito sagrado de lei corresponderia a um desígnio secreto cujo sentido poderia ser revelado pela decisão racional capaz de adotar o método correto de interpretação.

O processo de objetivação da lei se fundava na convicção segundo qual a própria lei incluiria o comando ao qual o juiz deveria sujeitar-se. A hermenêutica tradicional não percebia que "toda interpretação é um ato autônomo de síntese criadora de um 'legislador', seja de uma interpretação extensiva ou intensiva" (Schmitt, 1912:33). Schmitt denuncia a ilusão da crença de que os procedimentos interpretativos poderiam capturar a vontade real da lei ou do legislador. De seu ponto de vista, "o legislador é construído, não reconstruído. O jurista que cria um sistema transforma o pensamento antigo e introduz um novo" (ibidem:32-33). Assim, deixava claro que toda interpretação implica atividade criativa, pois é impossível reconstruir a vontade ou conteúdo de uma lei. Sua crítica à insuficiência do método "construtivo" reside na limitação da linguagem, "das palavras e expressões" empregadas. Em sua opinião, "o legislador é construído como o homem na lua".

Os métodos de interpretação se distanciavam da realidade ao buscarem um sentido racional independente da vontade decisória dos homens:

Os atuais métodos de interpretação se desenvolveram no decorrer do século - de forma independente da finalidade de encontrar uma deci- 
são judicial correta - a partir da confusão dos métodos de interpretação teológico, filosófico e histórico em conexão com o cargo público do juiz, portanto, a partir de elementos heterogêneos. (ibidem:38)

Posteriormente, o positivismo jurídico buscará eliminar o sincretismo metodológico a fim de alijar qualquer método cuja adoção abrisse o sistema a conteúdos estranhos ao direito. Desse modo o direito torna-se ainda mais abstrato e desenraizado de uma decisão fundada na experiência. Contra a racionalização positivista do direito resultante de sua sublimação, hipóstase e emancipação da particularidade da realidade concreta, Schmitt contrapõe o sentido secularizante do seu conceito de decisão, que não nasce de norma abstrata, mas cria um direito concreto para a realidade carente de sentido, forma e orientação. A estrutura da vida social não advém da lei abstrata e genérica, mas da normatividade concreta da decisão que, ao ser tomada, elimina virtuais possibilidades normativas em detrimento de uma escolha concreta, redutora de complexidade e configuradora da ordem jurídica.

\section{ALCANCE E LIMITE DO MOVIMENTO DO DIREITO LIVRE}

Na primeira década do século passado, Carl Schmitt toma conhecimento da teoria do movimento do direito livre, cujo conteúdo desempenhará importante papel para sua crítica à hermenêutica tradicional cunhada pelo positivismo jurídico. A pretensão do movimento do direito livre, cujo representante principal era Eugen Ehrlich (1862-1923), consistia em libertar o direito da interpretação canônica que o reduzia a um sistema de normas jurídicas.

Algumas objeções de Schmitt ao método da "hermenêutica tradicional", elaborado pela jurisprudência dos conceitos, não diferem da crítica do movimento do direito livre ao positivismo jurídico. Seu ponto coincidente, porém, restringe-se aos mencionados "métodos lógicos de interpretação" adotados para a interpretação da lei. Ao contrário da crítica sofrida à época da publicação de Gesetz und Urteil, suas ideias divergiam essencialmente daquelas do movimento do direito livre. Concordava quanto ao fato de o direito ser um fenômeno social que integrava a sociologia (Ehrlich, 1986:26). No entanto, discordava do método dedutivo pelo qual o movimento do direito livre inferia normas jurídicas de elementos sociais suprapositivos. Schmitt reputava os defensores do movimento do direito livre, a exemplo de Ehrlich, como seguidores do direito natural. A necessidade de suprir as lacunas do 
sistema jurídico mediante a derivação de normas de conteúdos suprapositivos parecia ressuscitar o direito natural. Na visão de Schmitt, o movimento do direito livre, ao ampliar as fontes do direito ${ }^{10}$, incidia no mesmo equívoco do positivismo jurídico, pois buscava a conformidade da decisão judicial com normas deduzidas de concepções idealizadas. Nem o direito natural moderno, nem o positivismo jurídico e tampouco o movimento do direito livre escapavam da crença em um método racional capaz de deduzir o direito positivo a partir de valores suprapositivos. A operação lógico-dedutiva encobria o caráter não dedutivo da decisão. A sentença, proferida por Schmitt, no trabalho Politische Theologie de 1922, segundo o qual a decisão deriva de um nada normativo, significa que o ato decisório apresenta um caráter indedutível, irracional, existencial.

Ora, se de um lado a incerteza da jurisprudência residia justamente no empenho da "hermenêutica tradicional" em subordinar a práxis jurídica à teoria do positivismo legalista por meio do "princípio da conformidade à lei", de outro lado, o movimento do direito livre ambicionava conformar a decisão a critérios "objetivos" exteriores à lei. Além disso, a proposta do movimento do direito livre de adequar a decisão a um princípio diferente da lei, como o "sentimento jurídico", não libertava a decisão judicial de um ideal normativo preso ao método da subsunção. Tanto a jurisprudência dos conceitos quanto o movimento do direito livre reduzem a decisão à aludida operação de subsunção: no primeiro caso, a decisão judicial do fato é submetida à norma legal correspondente; no segundo, é submetida a uma dimensão "suprapositiva" ou extrajurídica, cuja fonte procede de "valores morais" ou "normas culturais".

O movimento do direito livre confronta a concepção de um sistema lógico e a teoria da conformidade à lei com a noção de "mentalidade" (Gemüter) que corresponde a um conjunto de sentimentos derivado do espaço interior da consciência. Na decisão judicial, embora proveniente da subjetividade e do voluntarismo do juiz, também se manifestaria um "sentimento jurídico". Esta noção seria um aspecto essencialmente presente nos fundamentos metajurídicos das sentenças judiciais, assim como também as "normas culturais" e as "convicções de valores morais do povo" (Schmitt, 1912:88). A lei positiva, portanto, seria apenas uma entre outras fontes da jurisprudência, sendo seu valor mitigado frente aos elementos "individuais e social-psicológicos", "empiricamente" observáveis na decisão. 
Na visão de Schmitt, entretanto, alguns pontos apresentavam um caráter especioso. Em primeiro lugar, a constatação da insuficiência da lei conduzia ao caminho da ampliação das fontes, sem, contudo, eliminar o mecanismo causal da justificativa da decisão. A argumentação da decisão com base numa fonte de qualquer sorte distorce o papel da fundamentação, já que "a fundamentação da decisão não deveria ser confundida com a explicação causal psicológica" (ibidem:18). Esse ponto é crucial, pois pelo menos setenta anos antes de trabalhos como o de Chaïm Perelman ${ }^{11}$, Schmitt já chamava a atenção para a necessidade de fundamentar as decisões judiciais. É notável que o jurista já salientasse, numa era tecnicista-positivista, que "a fundamentação pertence à decisão" (Schmitt, 1912:18). O caráter sintético da declaração não deve ofuscar seu significado subjacente: o fundamento de validade de uma decisão não pode ser encontrado em um sistema fechado de normas. O resultado da decisão não se sujeita a pressupostos, sejam lógicos, psicológicos, sociais ou morais. A decisão não é deduzida do mundo conceitual abstrato, mas reside na realidade terrena da experiência concreta.

Aqui é possível perceber o empenho de Schmitt em secularizar a ideia de determinação do direito dos conceitos abstratos da teoria do positivismo jurídico e em torná-la efetiva no plano contingente da vida real. Não se pode deixar de ver que desde a instituição da doutrina da separação dos poderes, os motivos constitutivos da lei não apenas se divorciam do conteúdo de sua criação, mas também de sua aplicação. Gesetz und Urteil mostra que a garantia do vínculo do juiz à lei escamoteia a submissão da vontade da autoridade estatal à arbitrariedade e imprevisibilidade manifestada na discricionariedade de decisões judiciais. Nas anotações de seu diário de 1912, o jurista observa que não se pode deixar de perceber que a lei desprende-se por meio da publicação de seu legislador - daí em diante deve ser compreendida por intermédio da relação sistemática, na qual seus preceitos jurídicos estão uns frente aos outros e ao direito já vigente -, surge de forma tão autônoma quanto a vontade publicada do Poder Legislativo, de modo que a vontade e o conhecimento de seu próprio autor se tornam indiferentes.

A passagem é consequência da investigação da relação entre forma e conhecimento e conhecimento e vida, na qual Schmitt examina o neokantismo de Stammler. Schmitt observa como o conhecimento do ponto de vista neokantiano é indiferente ao conteúdo. O caráter formal do modo de conhecimento neokantiano permite estabelecer um dualismo 
entre forma e matéria, conhecimento e vida. Apesar da influência do neokantismo nos primeiros escritos de Schmitt, é notável a independência com que o autor incorpora essas ideias, a fim de acentuar, sobretudo, o dualismo existente entre a forma abstrata da lei e o conteúdo da vontade, entre o método de aplicação da lei e o resultado da decisão.

O critério da decisão correta de Schmitt não é retirado da existência da lei, do sentimento jurídico, tampouco da norma cultural, mas da prática jurídica e suas consequências. Em segundo lugar, a explicação causal de natureza psicológica ou sociológica da decisão não oferece um critério ou valor capaz de se distinguir em meio ao turbilhão da faticidade da realidade e tornar efetivo o postulado da determinação do direito. Em terceiro lugar, a derivação da decisão de explicações psicológicas e sociológicas seria, no fundo, procedente de "valorações 'pessoais' subjetivas de uma atividade dirigida atribuída ao juiz", seriam "fenômenos (Vorgänge) 'voluntaristas' salientados no momento da fundamentação da decisão" (Schmitt, 1912:98). Uma das principais causas da indeterminação do direito reside na incapacidade de se distinguir entre interior e exterior. Em outras palavras, são aspectos que se desenrolam no interior do mundo mental do indivíduo que seriam considerados como fatos da realidade externa. Assim, o "sentimento jurídico" do juiz seria uma fonte de ilação de valores aptos a orientar condutas: "pretender derivar da necessidade da pessoalidade relevante (Persönlichkeit) do juiz seria um equívoco no qual se originaria a confusão de valores pessoais com o seu uso e representação" (Schmitt, 1912:98). O objeto do direito e, portanto, da decisão, são fatos externos visíveis ou fenômenos capazes de se manifestar, adquirindo uma forma inteligível no plano da realidade. O que se desenrola no espaço interior da consciência não deve ser confundido com as manifestações externas da realidade presente.

A preocupação de Schmitt em salientar o dualismo entre teoria e práxis, interior e exterior, lei e decisão, também se refere à convicção de uma relação de causalidade cujo efeito é apagar as diferenças entre interior da consciência e o exterior da realidade. Por isso, o positivismo podia afirmar que a lei o é porque é lei. Neste caso, as repreensões de Schmitt valem tanto para o movimento do direito livre quanto para a jurisprudência dos conceitos. Todavia, poder-se-ia indagar se o postulado do qual deriva o critério da decisão correta investigada por Schmitt não seria uma ideia particular sem apelo externo. A resposta é 
dada pela práxis, isto é, postulado reconhecido pela práxis orientada da realização do direito.

O movimento do direito livre, apesar de criticar os métodos de interpretação da hermenêutica tradicional, conservou o método da subsunção. De acordo com o referido movimento, se a subsunção à lei não apresentasse um resultado correto, a falha residiria na lei de modo que a lei deveria ser alterada para advir o resultado correto:

que essa é a ideia condutora do movimento do direito livre. Na medida em que posiciona um direito livre, "suprapositivo", extraído, por exemplo, de juízos, valores morais ou "normas culturais" ao lado do direito "positivo" e, assim, compreende como decisões legais algo mais amplo do que o método tradicional, mantém formalmente de pé o critério da legalidade (Gesetzlichkeit) e trilha no mesmo caminho da "teoria da interpretação tradicional", que também queria ampliar o conteúdo da lei, mas não tinha desse modo, logrado o êxito desejado. (Schmitt, 1912:40)

A passagem revela que o movimento do direito livre seguia os mesmo passos da vertente positivista da jurisprudência dos conceitos ao manter-se formalmente fiel ao critério legalista de adequação da decisão a uma ideia previamente estabelecida. De sua perspectiva, não importava o fato de tal ideia encontrar-se além da "vontade do legislador" ou da "lei". O caráter misterioso e imperscrutável do desígnio secreto dessa "vontade" obrigava tanto a jurisprudência dos conceitos quanto a qualquer adversário desta corrente à investigação e, consequentemente, à construção do conteúdo da lei.

O movimento do direito livre não havia conseguido solapar, nem sequer abalar, o paradigma positivista do direito. Ao contrário, sua ambição de ampliação das fontes do direito conduzia à subsunção da realidade na construção de distintas imagens do que seria esta realidade. A insistência no critério ideal da fonte do direito conservava a ideia da decisão como subsunção do caso concreto à correspondente fonte ideal de interpretação. Além disso, sua crítica aos métodos lógicos de interpretação não havia se dirigido à fonte principal da arbitrariedade da decisão judicial: a primazia do método subsuntivo ${ }^{12}$, que tinha sido elevado a um fim em si mesmo e equiparado à decisão correta. O método da subsunção não havia sido abandonado, pois assim como ocorria no positivismo, ainda era visto como garantia fundamental da segurança jurídica positivista. Na medida em que o emprego do método 
subsuntivo tinha se tornado sinônimo de decisão correta, a decisão do caso concreto presente era relegada a um segundo plano. A subsunção não é, evidentemente, um problema em si, pois pode ser tratada como instrumento empregado para determinado fim.

Contudo, ao se compreender a decisão correta pela adequada subsunção do fato à norma anterior, convertia-se a subsunção num fim em si mesmo. Desse modo, a legitimidade de uma decisão pela via da subsunção residiria na sua conformidade com o princípio da anterioridade. A condição de validade da decisão derivaria da satisfação de um $a$ priori pela via da subsunção. A subsunção como finalidade da decisão judicial pressupõe um elo imediato entre a teoria do direito e a práxis jurídica, entre o fato suposto na estrutura universal da norma e a decisão sobre o fato da realidade. Tais ideias confundem a subjetividade com a objetividade, o particular com o geral, os meios com os fins.

Em primeiro lugar, a preocupação de Schmitt de se orientar pela prática jurídica, e não pela lei, demonstra que qualquer norma jurídica, moral ou cultural somente adquire sentido por meio de uma decisão. De sua perspectiva, a decisão é a ação capaz de conferir energia, vida e sentido à letra morta da lei.

Em segundo lugar, a decisão não se legitima por meio de algo previamente dado como a lei, pois a legitimidade não deriva da legalidade. A legitimidade não pode ser subentendida, pressuposta ou subsumida pela mera promulgação de uma lei. Na visão schmittiana, a legitimidade não é estabelecida a priori pela lei, mas alcançada a posteriori pela decisão. Mas para que isto ocorra, os efeitos da decisão precisam realizar no mundo concreto o postulado da determinação do direito. Não é a existência prefixada de uma lei que a legitima automaticamente, mas a observação empírica da concordância dos efeitos da decisão e o postulado da determinação do direito. Por isso, Schmitt afirma que a decisão tem que ser fundamentada, pois a sua finalidade é persuadir.

Em terceiro lugar, por meio de seu conceito de decisão Schmitt introduz um fator dinâmico de concretização do direito no lugar estático da lei positiva (Schmitt, 1912:88). Em virtude disto, adverte para o equívoco da transformação de meios em fins, uma vez que a norma - seja ela jurídica ou de qualquer outra espécie -, bem como seu método de subsunção, são apenas ferramentas. Consequentemente, "considerou-se o meio para alcançar a determinação do direito como um fim em 
si (ora a 'lógica', ora a 'construção', ora a 'norma livre do direito')" (ibidem:95).

\section{CONCLUSÃO}

O propósito deste artigo foi mostrar a relevância do repertório conceitual de Carl Schmitt à reflexão política. Seus escritos contribuíram com a inflexão e ampliação semântica de conceitos fundamentais que hoje integram o vocabulário da teoria política. As acepções que confere aos conceitos de decisão, soberania, secularização, exceção, teologia política e contingência são ferramentas imprescindíveis aos estudos dedicados à compreensão da fronteira entre direito e política.

Revisitar os escritos de juventude do jurista alemão representa um aporte no sentido de ampliar a compreensão do instrumental conceitual legado por sua obra. Voltar aos primeiros trabalhos de Carl Schmitt possibilita elucidar seus conceitos e verificar suas apropriações - por vezes um tanto enviesadas, como se nota em Giorgio Agamben - no âmbito do debate da teoria política contemporânea.

O filósofo italiano não percebe, por exemplo, como Schmitt vinha desde seus primeiros escritos alertando para a ampliação do estado de exceção em virtude da progressiva perda do monopólio da decisão pelo Estado. Por um lado, o fetichismo da lei resultava no deslocamento da decisão para o Poder Legislativo, provocando paralisia e indeterminação. Por outro, o governo alemão se convertia, a partir do início da década XX, numa máquina de medidas provisórias. A exceção como paradigma de governo, tese central apresentada por Agamben em Estado de Exceção, já havia há muito tempo sido formulada por Carl Schmitt ao alertar para a aceleração de expedição de decretos e medidas provisórias por parte do Poder Executivo (2003a:407). Além disso, ao filósofo italiano escapa um dos principais papeis que desempenha a exceção no pensamento do jurista alemão. Trata-se, do estatuto epistemológico da exceção que corresponde nos seus escritos a um ponto de vista, um modo de compreender a realidade que não parte do curso regular da vida ordinária, mas da sua observância a partir de uma situação limite, de uma situação extrema, capaz de provocar a abertura da regularidade mecânica da vida social até o limiar. A exceção como método heurístico seria capaz de expor as condições de criação e manutenção da regularidade da realidade. A exceção, assim como a contingência nos primeiros escritos de Schmitt, revela um traço heurístico presente em 
toda obra do jurista. Consiste em um método voltado à compreensão da realidade concreta capaz de desvelar seu modo de funcionamento a partir de uma decisão de uma instância soberana.

O retorno a um dos primeiros textos de Schmitt sobre a lei e o julgamento permite, também, desfazer interpretações equivocadas a exemplo daquela de Heinrich Meier, em seu Die Lehre Carl Schmitts. Vier Kapitel zur Unterscheidung Politischer Theologie und Politischer Philosophie (A Teoria de Carl Schmitt. Quatro Capitulos sobre a Diferença entre Teoria Política e Filosofia Política) de 1994. O desconhecimento dos primeiros trabalhos de Schmitt, como é o caso de Gesetz und Urteil, e a incapacidade de compreender o sentido secularizante, conduzem a equívocos, como o de supor que "a teologia política pressupõe a crença na verdade da revelação" (Meier, 2004:40).

O desinteresse pelos textos de juventude de Schmitt pode estar associado, entre outras razões, ao fato de não se encontrar neles nenhum indício de um fundamento religioso ou de uma tentativa de teologizar o jurídico e o político. Muito pelo contrário, o autor denuncia a onipotência do legislador e o sentido sagrado atribuído à lei. Além disso, se empenha em secularizar o direito ao deslocar a atenção da lei para a decisão. O sentido secularizante das ideias schmittianas corresponde à necessidade de emancipar a decisão de seus pressupostos normativos. Penso que a investigação de Gesetz und Urteil obriga certas interpretações dos trabalhos de Schmitt a uma cuidadosa revisão. Este é o caso da interpretação de Heinrich Meier, que parece tomar como ponto de partida de sua investigação o catolicismo de Schmitt e não as ideias apresentadas pelo autor.

O sentido secularizante das ideias do jurista alemão busca reconduzir a racionalidade do pensamento moderno e sua tendência à universalização de valores morais à realidade da vida concreta. Secularizar implica trazer teorias positivistas e liberais do Estado do alto de sua abstração e generalização ao solo da existência terrena dos homens. Em seu escrito sobre a lei e a decisão, Schmitt denuncia que o positivismo jurídico, ao sacralizar o conceito de lei, reduz o decidir e agir políticos a operações de apreensão da "vontade do legislador" ou "da lei", o que relegava o juiz, e, consequentemente, toda práxis jurídica a um "estado de necessidade". Schmitt acusava os representantes do positivismo jurídico de conferir um fundamento teológico ao direito. A redução do direito a um conjunto de normas abstratas dotadas de uma vontade 
imanente não poderia se manter senão por meio da fé nas leis da causalidade das ciências naturais que serviam de paradigma para o positivismo jurídico e suas derivações.

A controvérsia em torno da vida e obra de Carl Schmitt não deve se converter em obstáculo à compreensão da relevância de seu pensamento no âmbito da teoria política e de outras áreas do conhecimento. Sua crítica ao positivismo jurídico, liberalismo e a elaboração de conceitos relevantes à compreensão das condições de possibilidade de sociedades complexas não devem ser relegados a um segundo plano. $\mathrm{O}$ inegável aporte de seu pensamento contribuiu para elucidar o caráter polissêmico e polêmico de conceitos políticos e jurídicos, abriu espaço para a compreensão da irredutibilidade do político e jogou luz sobre a relação entre soberania, decisão e secularização.

(Recebido para publicação em 22/7/2015) (Reapresentado em 25/6/2016 e 24/11/2016) (Aprovado para publicação em 1/6/2017 


\section{NOTAS}

1. Neste artigo utilizo a primeira edição do livro Gesetz und Urteil de 1912, que encontrei no acervo do arquivo de Carl Schmitt situado em Düsseldorf. A despeito de ter traduzido o termo Urteil por julgamento, seu significado também corresponde à ideia de sentença, veredicto, decisão judicial, juízo, apreciação, parecer etc. Talvez a tradução mais adequada fosse Lei e decisão judicial, porém Schmitt é muito meticuloso com os termos e ora usa Urteil e richterliche Entscheidung (decisão judicial) como sinônimos, ora os diferencia, o que dificulta a tradução. Neste artigo todos os trechos em alemão foram traduzidos por mim.

2. O livro Secularização Inacabada. Política e Direito no Pensamento de Carl Schmitt é uma exceção nesse sentido, uma vez que trata dos primeiros escritos de Schmitt em seus dois capítulos iniciais (Castelo Branco, 2011).

3. A decisão soberana cria e dá forma a uma existência coletiva, o que corresponde ao político. Já a política, é o modo singular e historicamente determinado dessa existência.

4. Neste artigo o termo jurisprudência não é empregado como decisão proferida por tribunal em grau de recurso, mas com o seu sentido antigo correspondente à "ciência do direito".

5. Ver Ellen Kennedy (2004:65).

6. Tal espécie de secularização é designada por Hermann Lübbe por secularismo e "surgiu a partir do iluminismo, recebendo então da Revolução Francesa um impulso rígido que foi adotado pelo liberalismo do século XIX" (Lübbe, 2003:132).

7. Comenta Schmitt que "a jurisprudência foi frequentemente colocada lado a lado com a matemática e invejada por seus conceitos claros e seguros, porque nela o fenômeno é, por assim dizer, objeto de estudo no espaço, e não na sequência temporal, como elemento de um todo de um organismo lógico" (1912:58).

8. Neste sentido, ver o trabalho Die Lehre Carl Schmitt. Vier Kapitel zur Unterscheidung Politischer Theologie und Politischer Philosophie (A teoria de Carl Schmitt. Quatro capítulos sobre a diferença entre teoria política e filosofia política), de Henrich Meier, publicado pela primeira vez em 1994. O desconhecimento dos primeiros trabalhos de Schmitt, como Gesetz und Urteil, e a incapacidade de compreender o sentido formal que o método da analogia desempenha nos seus trabalhos, leva a graves equívocos, como o de supor que "a teologia política pressupõe a crença na verdade da revelação" (Meier, 2004:40). O desinteresse pelos primeiros trabalhos de Schmitt pode estar associado, entre outras razões, ao fato de não se encontrar neles nenhum indício de fundamento religioso ou tentativa de teologizar a esfera do direito e da política. Ao contrário, o autor denuncia a onipotência do legislador e o sentido sagrado e absoluto atribuídos à lei. Além disso, se empenha em secularizar o direito ao deslocar a atenção da lei para a decisão. Entendo que a investigação de Gesetz und Urteil obriga certas interpretações dos trabalhos de Schmitt a uma cuidadosa revisão. Este é o caso da interpretação de Heinrich Meier, que parece tomar como ponto de partida de sua investigação a origem católica de Schmitt, e não as ideias apresentadas pelo autor.

9. Binding, Wach e Kohler eram os representantes mais conhecidos da teoria objetiva da interpretação e defendiam que a "opinião dominante" teria declarado o "conteúdo objetivo das ideias da lei" como decisivo, buscando, dessa forma, eliminar o con- 


\section{Pedro H. Villas Bôas Castelo Branco}

teúdo subjetivo da investigação da vontade do legislador (Schmitt, 1912:30). A lei deixava de ser vista como um conteúdo fixo e inalterável e passava a ser concebida como "força viva constante". Segundo Schmitt, "a vontade que a aplicação do direito pretende satisfazer é o seu próprio segredo que não se torna claro com a expressão 'organismo vivo'"' (Schmitt, 1912:27-36). Os representantes da teoria objetiva da lei acreditavam numa razão contida na lei que ao ser reconduzida em um conceito geral poderia ser apreendida (Larenz, 1966:47-50).

10. Schmitt emprega a expressão "fiatjustitia, pereatmundus" (faça-se a justiça, mesmo que pereça o mundo) a fim de mostrar que o movimento do direito livre agia de forma semelhante à corrente do direito natural ao buscar aferrar a decisão à visão idealizada das fontes suprapositivas. Ironicamente observa Schmitt: “é possível, hoje, falar do direito natural sem ser considerado um ideólogo ou fantasista (Phantast) e a frase 'fiatjustitia, peratmundus', que é somente uma expressão particularmente eficiente do ideal da conformidade à fonte (Quellenmässigkeit) de toda decisão, perdeu em vigor motivador e popularidade, não podendo sequer valer como desculpa" (Schmitt, 1912:16). A ideia da expressão, precisamente de que a justiça deve realizarse mesmo que o mundo caia em ruína, poderia trazer a recordação dos olhos vendados da Justitia.

11. Cf. Perelman (2000:210-211).

12. A crítica de Schmitt ao método subsuntivo liga-se ao empenho em denunciar a ilusão, a "fetichização da lei" (Schmitt, 1912:25). A suposição de que a forma universal da lei é capaz de abarcar em si a realidade complexa, estimula a indeterminação do direito que o positivismo pretendia evitar. A admissão do positivismo da concepção da decisão correta como decisão em conformidade à lei levou ao "equívoco de aceitar como seu ponto de partida a conformidade à lei representada como critério correto e com isso começaram as conhecidas falhas lógicas de inferir da identidade dos predicados na identidade dos sujeitos. A conclusão: decisões em conformidade à lei são corretas, encontra-se no mesmo nível que: todos os caucasianos são homens; se, portanto, esquimós são homens, eles têm que ser caucasianos" (Schmitt, 1912:88). 


\section{REFERÊNCIAS BIBLIOGRÁFICAS}

AGAMBEN, Giorgio. (2004), Estado de Exceção. São Paulo, Boitempo.

BECKER, Hartmut. (2003), Die Parlamentarismuskritik bei Carl Schmitt und Jürgen Habermas. Berlin, Duncker \& Humblot.

CASTELO BRANCO, Pedro H. Villas Bôas. (2011), Secularização Inacabada: Política e Direito no Pensamento de Carl Schmitt. Curitiba, Appris.

EHRLICH, Eugen. (1986), Fundamentos da Sociologia do Direito. Brasília, Ed. UnB.

FERREIRA, Bernardo. (2004), O Risco do Político. Belo Horizonte, Ed. UFMG.

HABERMAS, Jürgen. (1990), Strukturwandel der Öffentlichkeit. Untersuchung zu einer Kategorie der bürgelichen Gesellschaft: Frankfurt am Main.

HOFMANN, Hasso. (2002), Legitimität gegen Legalität. Der Weg der politischen Philosophie Carl Schmitts. 4a ed. Berlin, Duncker \& Humblot.

KELSEN, Hans. (1960), Hauptprobleme der Staatsrechtslehre. Entwickelt aus der Lehre vom Rechtssatze.Aalen, Scientia.

LARENZ, Karl. (1966), Metodología de la Ciencia del Derecho. Barcelona, Ariel.

LEPPER, Alexander; SCHMITZ, Alexander (orgs.). (2007), Hans Blumenberg Carl Schmitt. Brief Wechsel 1971-1978. Frankfurt am Main, Suhrkamp.

LÜBBE, Hermann. (2003), Säkularisierung. Geschichte eines ideenpolitischen Begriffs. 3a ed. München, Alber Studienausgabe.

KENNEDY, Ellen. (2004), Constitutional Failure. Carl Schmitt in Weimar. London, Duke University Press.

MEIER, Heinrich. (1998), Carl Schmitt, Leo Strauss und "Der Begriff des Politischen". Zu einem Dialog unter Abwesenden. Stuttgart, Weimar, Metzler.

. (2004), Die Lehre Carl Schmitts. Vier kapitel zur Unterscheidung Politischer Theologie und Politischer Philosophie. 2a ed. Stuttgart, J.B. Metzler.

PERELMAN, Chaïm. (2000), Lógica Jurídica. São Paulo, Martins Fontes.

RUMPF, Helmut. (1972), Carl Schmitt und Thomas Hobbes. Ideelle Beziehung und aktuelle Bedeutung: mit einer Abhandlung über die Frühschriften Carl Schmitts. Berlin, Duncker \& Humblot.

SCHMITT, Carl. (1910), Über Schuld und Schuldarten. Eine terminologische Untersuchung. Breslau, Schletter'sche Buchhandlung.

. (1912), Gesetz und Urteil. Eine Untersuchung zum Problem der Rechtspraxis. Berlin, Verlag von Otto Liebmann.

. (1993), Über die drei Arten des rechtwissenschaftlichen Denkens. 2aㅡ ed. Berlin, Duncker \& Humblot.

. (1994a), Die Diktatur. Von den Anfängen des modernen Souveränitätsgedankens bis zum proletarischen Klassenkampf. 6a ed. Berlin, Dunckler \& Humblot.

. (1994b), Positionen und Begriffe: im Kampf mit Weimar. 3a ed. Berlin, . (1998c), Legalität und Legitimität. 6a ed. Berlin, Duncker \& Humblot.

DADOS - Revista de Ciências Sociais, Rio de Janeiro, vol. 60, n־ 4, 2017 


\section{Pedro H. Villas Bôas Castelo Branco}

. (1998c), Politische Romantik. Berlin, Duncker \& Humblot.

. (2002), Der Begriff des Politischen. Text von 1932 mit einem Vorwort und drei Corollarien.

7a ed. Berlin, Duncker \& Humblot.

. (2003a) [1943/1944],“Die Lage der europäischen Rechtswissenschaft”, in Verfassungsrechtliche Aufsätze aus den Jahren 1924-1954. 4a ed. Berlin, Duncker \& Humblot.

. (2003b), Verfassungslehre. Berlin, Duncker \& Humblot.

(2003c),Verfassungsrechtliche Aufsätze aus den Jahren 1924-1954. 4a ed. Berlin, Duncker \& Humblot.

. (2004a), Der Wert des Staates und die Bedeutung des Einzelnen. 2ae ed. Berlin, Duncker \& Humblot.

. (2004b), Politische Theologie. Vier Kapitel zur Lehre von der Souveränität. 8a ed. Berlin, Duncker \& Humblot.

. (2007) "Carta a Hans Blumenberg, de 31 de março de 1971", in A. Schmitz; M. Lepper (org.), Hans Blumenberg. Carl Schmitt. Briefwechsel 1971-1978. Frankfurt am Main, Suhrkamp, pp.111 e 112.

WEBER, Max. (2005), Wirtschaft und Gesellschaft. Grundriss der verstehende Soziologie. Frankfurt am Main, Zweitausendeins. 


\section{RESUMO}

Decisão e Secularização na Reflexão de Juventude de Carl Schmitt

Este artigo se propõe a jogar luz em escritos de juventude de Carl Schmitt a fim de salientar sua relevância para a compreensão de alguns dos conceitos mais importantes elaborados ao longo de sua reflexão político-jurídica. A despeito de tais trabalhos, redigidos entre 1910 e 1914, serem pouco conhecidos, parte deles contém o estágio inicial do desenvolvimento de conceitos não apenas imprescindíveis à compreensão de sua obra, mas também à elucidação de terminologia central no vocabulário da teoria política contemporânea. O presente estudo revisita sobretudo um dos primeiros trabalhos de Schmitt com intuito de elucidar o percurso de elaboração dos conceitos de decisão, secularização, exceção e teologia política. Recuperar seus escritos até hoje relegados a segundo plano e iluminar a construção de alguns conceitos, não só permite questionar interpretações que os negligenciam como também chamar a atenção para a atualidade de suas ferramentas conceituais.

Palavras-chave: lei; vontade; sacralização; secularização; decisão

\section{ABSTRACT \\ Decision and Secularization in Reflections Made by a Young Carl Schmitt}

This article aims to shed light on writings of the young Carl Schmitt in order to highlight their relevance to an understanding of several of the most significant concepts developed throughout Schmitt's political-legal reflections. Despite the fact that such works - written from 1910 to 1914 - remain relatively unknown, sections of them contain early glimpses of the development of concepts that are not only indispensable to an understanding of Schmitt's works, but also to a clarifying of vocabulary central to contemporary political theory. In this context, the present study reviews one of Schmitt's earliest works with the aim of revealing how the concepts of decision, secularization, exception, and political theology were developed. Reviewing works by the author relegated until now to the secondary sphere thus sheds light on the shaping of several concepts, not only allowing us to question interpretations to have neglected them, but also drawing our attention to the current relevance of Schmitt's conceptual tools.

Key words: law; will; sacralization; secularization; decision 
RÉSUMÉ

Décision et Sécularisation dans la Réflexion de Jeunesse de Carl Schmitt

Cet article se propose de mettre en lumière les écrits de jeunesse de Carl Schmitt afin d'en souligner la pertinence pour la compréhension de certains des concepts les plus importants élaborés tout au long de sa réflexion politico-juridique. Même si ces travaux rédigés entre 1910 et 1914 demeurent peu connus, une partie d'entre eux contient l'étape initiale du développement de concepts non seulement indispensables à la compréhension de son œuvre, mais également à l'élucidation de la terminologie centrale du vocabulaire de la théorie politique contemporaine. La présente étude revisite surtout l'un des premiers textes de Schmitt dans le but d'analyser le parcours d'élaboration des concepts de décision, de sécularisation, d'exception et de théologie politique. Remettre au goût du jour ces écrits jusqu'aujourd'hui relégués au second plan et éclairer la construction de certains concepts ne nous permet pas seulement de remettre en question des interprétations qui les auraient négligés, mais également d'attirer l'attention sur l'actualité de ces outils conceptuels.

Mots-clés : loi ; volonté ; sacralisation ; sécularisation ; décision

\section{RESUMEN}

Decisión y Secularización en las Reflexiones de la Juventud de Carl Schmitt

Este artículo se propone arrojar luz sobre los escritos de juventud de Carl Schmitt con el fin de destacar su relevancia para comprender algunos conceptos más importantes elaborados a lo largo de su reflexión político-jurídica. Aunque estos trabajos, escritos entre 1910 y 1914, son poco conocidos, parte de ellos contiene la fase inicial del desarrollo de conceptos que no solo resultan imprescindibles para comprender su obra, sino también para elucidar la terminología central del vocabulario de la teoría política contemporánea. El presente estudio revisa sobre todo uno de los primeros trabajos de Schmitt, con la intención de explicar el proceso de elaboración de los conceptos de decisión, secularización, excepción y teología política. Recuperar sus escritos hasta hoy relegados a un segundo plano e iluminar la construcción de algunos conceptos no solo permite cuestionar interpretaciones que los ignoran, sino también hacer hincapié en la actualidad de sus herramientas conceptuales.

Palabras clave: ley; voluntad; sacralización; secularización; decisión 